Cordova Jurnal

ISNN (P) 2302-3155

(e) 2714-5808

Vol. 9, No. 22019
Jurnal Kajian Bahasa, dan Budaya Terbit 2 kali setahun oleh UPT. Pusat Pengembangan Bahasa (P2B) UIN Mataram. Tersedia Online pada https://journal.uinmataram.ac.id/index.php/cordova

\title{
Pedagogical Knowledge of English Teachers on Speech Acts in Senior High School Level of West Nusa Tenggara
}

\author{
Kamarudin $^{1}$ \\ kamarudin.ntbe@gmail.com
}

\begin{abstract}
As an English teacher, communicating through English language properly and thoroughly is highly required particularly at Senior High School level. They are expected to communicate politely since teachers are the role model of teaching. As a professional teacher, English teachers must have professional competencies such as speech acts proficiencies. Speech act is included into spoken English and is taught in Senior High School level in order to develop students' communicative competence. This is a descriptive qualitative research and is aiming at describing pedagogical knowledge of English teachers on speech acts in Senior High School level of West Nusa Tenggara. The knowledge itself is divided into some branches, they are the ability to define speech acts, ability to identify speech acts conversation and ability to identify speech act utterances. The researcher conducted the interview to collect the data. The data are obtained from the interview and the tape recorder to record the interview process. After analyzing the data, the researcher found that Senior High School teachers mostly can answer questions about speech acts. They can define speech acts, they can identify the speech act conversations and they can identify the speech act utterances. In conclusion, the knowledge of speech acts of Senior High School teachers is categorized very good because they can answer most questions correctly. Therefore, Senior High School teachers fulfill professional language competencies; they comprehend teaching materials and have good pedagogical skills.
\end{abstract}

Key Words: Pedagogical Knowledge, Speech Acts, Senior High School Teachers.

\section{NTRODUCTION}

In the context of language teaching, English teachers have special characteristic that maybe a bit different from the other teachers. They are different at performing communicative competence which of course not only teaching about the structure but also sharing ideas of understanding the culture of the language. In this case, acquiring speech acts is one of the ways for teaching how share and communicate thoroughly and properly. Thus, for the English teachers, the comprehending of teaching materials; speech acts 
Cordova Jurnal

ISNN (P) 2302-3155

(e) 2714-5808

Vol. 9, No. 22019
Jurnal Kajian Bahasa, dan Budaya Terbit 2 kali setahun oleh UPT. Pusat Pengembangan Bahasa (P2B) UIN Mataram. Tersedia Online pada https://journal.uinmataram.ac.id/index.php/cordova

competence is as important as the socio-cultural competence of the target language.

Finocchiaro (1989: 22) reveals that a teacher is considered as one of the important keys to successful language learning. Moreover, s/he is also a person who is actually involved in the teaching and learning process. Definitely, someone who has consciously chosen a professional job as a teacher can be said respectfully that s/he was proposing his/her self to be a guide for his/her students to make their life better.

Senior High School teachers should understand speech acts as it is composed the teaching materials. But in fact, the greater attention is put to genre and short functional text, while speech acts gets less attention. Teachers rarely teach speech acts or just skip some of them, because of many reasons, and they usually underestimate it. The expressions used in speech acts are the simple and daily expressions for various usages, so there is a tendency to consider it below other materials.

Speech acts are highly necessary for students of English as foreign language, particularly at Senior High School level, the students will learn the basic expression/utterances of daily conversation for their speaking communication skill; transactional or interactional.

Besides, conversation is the interchange of ideas; it is the willingness to communicate thought on all subjects, personal and universal, and in turn to listen to the sentiments of others regarding the ideas advanced, Conklin, (2009:12). And a great deal of human interaction is characterized by the primarily interpersonal rather than the primarily transactional use of language, Brown \& Yule, (1983:3).

So, teacher often gets difficulties at teaching spoken production, whether it is in managing the class, the students and the time, so that every student gets equitable chance to speak and to listen to someone. Especially for speech acts, teachers are needed to be well trained to master each speech act components and know how to apply it in socio-cultural context.

In this level, students are firstly taught about the various kinds of speech acts. So, they may get difficulties at understanding them since speech acts in Senior High School level are so vary.

Therefore, this study is conducted in purpose of finding pedagogical knowledge of English teachers on speech acts detailing on teachers to define, identify speech acts; speech acts conversations, and speech acts utterances. 


\section{METHODOLOGY}

This study employed descriptive qualitative approach. There were two English teachers were asked as the subjects of the study. Teacher $A$ is a new and less experienced teacher, and teacher $B$ is more longtime and richly experienced teacher. This research took the researcher as the key instrument. And interview was used to collect the data.

The interview was conducted informally in pleasant situation. The teachers did not feel under pressure so that the data gathered was fair and pure. The data was analyzed inductively. Qualitative research is fundamentally interpretive. It meant that the researcher made an interpretation of the data. Some steps were done; organizing and preparing the data for analysis, reading through all the data, using the coding process to generate a description of the subjects as well as categories or themes for analysis, advancing how the description and themes were represented, and the final step in data analysis involved making an interpretation of the data to find out the answers of research questions.

\section{DISCCUSSIONS}

\section{Defining Speech Acts}

Teacher $A$ and teacher $B$ are knowledgeable, because they are able to identify the speech acts characteristics. Although there was misperception, but they could state the differences and also mention the examples of speech acts.

\begin{tabular}{|l|l|}
\hline $\mathrm{R}$ & $\begin{array}{l}\text { In English teaching materials, the term speech acts is introduced, then what } \\
\text { is the definition of speech acts? }\end{array}$ \\
\hline $\mathrm{T} / \mathrm{A}$ & It is how we talk easily and correctly \\
\hline $\mathrm{R}$ & $\begin{array}{l}\text { Kompetensi dasar in SI for English, the term speech act is introduced, and } \\
\text { then what do you know about speech acts? }\end{array}$ \\
\hline $\mathrm{T} / \mathrm{B}$ & $\begin{array}{l}\text { Eee... speech acts, tindak tutur, it is familiar term. It refers more to the } \\
\text { spoken English. So that is how children learn certain speech acts to } \\
\text { communicate. One example, when a child wants to invite someone, } \\
\text { then what kind of formal speech acts that must be used. That's the spoken } \\
\text { one, but the written one is different, it's not speech acts, but the generic } \\
\text { structure. So speech act is how the way to communicate orally, either } \\
\text { formally or informally. }\end{array}$ \\
\hline &
\end{tabular}

\section{Identifying Speech Acts Conversation}

Teachers $A$ and teacher $B$ are knowledgeable because both of them are able to mention the kinds of speech acts conversations, and are able to state the differences between transactional and interpersonal conversations, and 
also are able to classify speech acts into transactional and interpersonal conversation. But Teacher B is more knowledgeable because most of his answers are correct.

\begin{tabular}{|l|l|}
\hline $\mathrm{R}$ & $\begin{array}{l}\text { When speech act is applied into a conversation, it can be divided into two } \\
\text { types, what are they? }\end{array}$ \\
\hline T/A & $\begin{array}{l}\text { Transactional and Interpersonal. } \\
\text { Interpersonal conversation is about courteousness, but transactional is clear, } \\
\text { I mean the position is clear. For example "good morning, Sir" is courteous } \\
\text { utterance, right? So greeting is interpersonal. And transactional, for } \\
\text { example "take me a glass of water please!" I'm sorry if they are overturned }\end{array}$ \\
\hline $\mathrm{R}$ & $\begin{array}{l}\text { When speech act is applied into a conversation, it can be divided into two } \\
\text { types, what are they? }\end{array}$ \\
\hline $\mathrm{T} / \mathrm{B}$ & $\begin{array}{l}\text { Hmm... it depends on the context of the dialogue, actually there are two } \\
\text { types, interpersonal and interpersonal texts, they are also can be used for the } \\
\text { term conversation. }\end{array}$ \\
\hline
\end{tabular}

\section{Identifying Speech Acts Utterances}

Both teacher A and teacher B are knowledgeable, because they are able to identify the utterances of speech acts.

\begin{tabular}{|c|c|}
\hline $\mathrm{R}$ & $\begin{array}{l}\text { There are two types of greetings. They are greeting a stranger and greeting } \\
\text { people who are already known. In your opinion, what is the difference? (In } \\
\text { terms of expression. }\end{array}$ \\
\hline T/A & $\begin{array}{l}\text { The example of greet people who are already known is "how are you?" for } \\
\text { greeting stranger, usually we use "how do you do?") }\end{array}$ \\
\hline $\mathrm{R}$ & $\begin{array}{l}\text { There are two types of greetings. They are greeting a stranger and greeting } \\
\text { people who are already known. In your opinion, what is the difference? (In } \\
\text { terms of expression. }\end{array}$ \\
\hline $\mathrm{T} / \mathrm{B}$ & $\begin{array}{l}\text { The utterances for people who are already known are such as "how are } \\
\text { you?", "Hi" or just call her name "Hi, Miss Sofi", but for stranger, usually } \\
\text { it's more polite "how do you do?" and the answer is "how do you do?" too. }\end{array}$ \\
\hline $\mathrm{R}$ & Politeness is taught in class, what are the examples of the utterances? \\
\hline T/A & $\begin{array}{l}\text { Some utterances contain politeness, it is being hard. So, one utterance can } \\
\text { contain some speech acts. It is hard to differentiate it then. }\end{array}$ \\
\hline T/B & $\begin{array}{l}\text { Express politeness, actually politeness can be included in all speech acts, } \\
\text { but usually it's for formal situation. For example, "could you please open } \\
\text { the window?" it is asking for help but polite, and then "excuse me, where is } \\
\text { the bank located?" it's asking for information but contains politeness. }\end{array}$ \\
\hline
\end{tabular}




\section{CONCLUSION}

Teacher $A$ (less experienced teacher) is capable enough in defining speech acts, identifying speech acts characteristics, conversations, and utterances but was not able to stating the differences between transactional \& interpersonal conversations and classifying speech acts into transactional \& interpersonal conversations.

Teacher $B$ (more experienced teacher) is knowledgeable in defining speech acts; identifying speech acts characteristics, conversations, and utterances. Thus, senior high school teachers in Mataram West Nusa Tenggara have good knowledge of speech acts.

Thus, Senior High School teachers had already fulfilled the teacher professional competence and professional language teacher competence, because they comprehend the teaching materials and have good pedagogical skills.

Thus, it is advised that Senior high School teachers should be able to identify, and define, and recognize how important speech acts is in their teaching, as well as applying speech acts in daily communication in order to become a professional teacher by fulfill professional language teaching competences.

\section{REFERENCES}

Agustien, Helena. I. R. 2004. The 2004 English Curriculum in A Nutshell (Paper): Presented at National Seminar The Teaching of EFL in Indonesia; A Reflection. 2 October 2004, Malang.

Austin, John L. 1962. How to Do Things with Words. Oxford: Oxford University Press.

Baleghizadeh, Sasan. 2007. Speech Acts in English Language Teaching. Iranian Journal of Language Studies (IJLS), Vol. 1(2), (pp. 143-154).

Bailey, Kenneth D. -. Methods of Social Researc: $2^{\text {nd }}$ Ed. - .

Brown, Gillian and George Yule. 1983. Discourse Analysis. Cambridge: Cambridge University Press.

Brown, H. D. 2001. Teaching by Principles: An Interactive Approach to Language Pedagogy. New York: Addison Wesley Longman, Inc.

Conklin, Mary Greer. 2009. Conversation: What to Say and How to Say It. -: The Floating Press.

Creswell, John M. -. Research Design: Qualitative, Quantitative and Mixed Methods Apptoaches. $2^{\text {nd }} \mathrm{Ed}$. 
Cordova Jurnal

ISNN (P) 2302-3155

(e) 2714-5808

Vol. 9, No. 22019
Jurnal Kajian Bahasa, dan Budaya Terbit 2 kali setahun oleh UPT. Pusat Pengembangan Bahasa (P2B) UIN Mataram. Tersedia Online pada https://journal.uinmataram.ac.id/index.php/cordova

Departemen Pendidikan Nasional. 2004. Standar Kompetensi Mata Pelajaran Bahasa Inggris SMP dan MTs. Jakarta: Depdiknas.

Dörnyei, Zoltan. 2007. Research Methods in Applied Linguistics. Oxford: Oxford University Press.

Finocchiaro, Mary. 1989. Some Facts about Language Teaching in the Elementary School: Teaching Children Foreign Language. New York: Mc Graw-Hill Book Company.

Halliday, M. A. K. 1975. Lzx earning How to Mean: Explorations in the Development of Language. London: Edward Arnold.

Harmer, Jeremy. 2001. The Practice of English Language Teaching. $3^{\text {rd }}$ Ed. England: Pearson Education Limited.

Hatch, Evelyn. 1992. Discourse and Language Education. Cambridge: Cambridge University Press.

Mackey, Alison and Susan M. Gass. 2005. Second Language Research: Methodology and Research. London: Lawrence Erlbaum Associates, Inc.

Nunan, David. 1992. Research Method in Language Learning. Cambridge: Cambridge University Press.

Olshtain, E., and A. D. Cohen. 1991. Teaching Speech Act Behavior to Nonnative Speaker. In M. Celce-Murcia (Ed). Teaching English as a Second or Foreign Language. New York: Newbury House.

Richards, Jack C. and Charles Lockhart. 1994. Reflective Teaching in Second Language Classroom. Cambridge: Cambridge University Press.

Searle, John. 1969. Speech Acts: An Essay in the Philosophy of Language. Cambridge: Cmabridge University Press.

Sukmadinata, Nana Syaodih. 2006. Metode Penelitian Pendidikan. Bandung: Remaja Rosdakarya.

Susanto. -. Writing a Scientific Essay: A Guide for the Writing of an Article. Surabaya: Universitas Negeri Surabaya.

. 2010. Silabus Dan RPP Mata Pelajaran Bahasa. Inggris untuk $S D / M I, \quad S M P / M t s$ dan SMA/MA. Surabaya: Universitas Negeri Surabaya.

Tillit, Bruce and Mary Newton Bruder. 1985. Speaking Naturally: Communication Skills in American English. Cambridge: Cambridge University Press.

Van Ek, J. A. 1975. The Threshold Level. Strasbourg: Council of Europe. Also Published in 1980 as Threshold Level English. Oxford: Pergamon. 

Mataram. Tersedia Online pada https://journal.uinmataram.ac.id/index.php/cordova

Wiersman, William. 1995. Research Methods in Education: An Introduction. Boston: Alley and Bacon.

Kumalarini, Th., et al. 2008. Contextual Teaching and Learning: Bahasa Inggris SMP/MTs Kelas VII. $4^{\text {th }}$ Ed. Jakarta: Departemen Pendidikan Nasional.

Wardiman, Artono, et al. 2008a. English in Focus: for Grade VII Junior High School (SMP/MTs). Jakarta: Departemen Pendidikan Nasional. . 2008b. English in Focus: for Grade VIII Junior High School (SMP/MTs). Jakarta: Departemen Pendidikan Nasional. . 2008c. English in Focus: for Grade IX Junior High School (SMP/MTs). Jakarta: Departemen Pendidikan Nasional.

Widiati, Utami, et al. 2008. Contextual Teaching and Learning: Bahasa Inggris SMP/MTs Kelas VIII. $4^{\text {th }}$ Ed. Jakarta: Departemen Pendidikan Nasiona.

Susilohadi, Gunarso, et al. 2008. Contextual Teaching and Learning: Bahasa Inggris SMP/MTs Kelas IX. $4^{\text {th }}$ Ed. Jakarta: Departemen Pendidikan Nasional. 